\title{
Effect of intracranial hypotension on cerebral blood flow
}

\author{
J. H. SALMON ${ }^{1}$ AND A. L. TIMPERMAN \\ From the Division of Neurosurgery, the University of Cincinnati College of Medicine \\ and Veterans Administration Hospital, Cincinnati, Ohio, U.S.A.
}

SUMMARY Intracranial hypotension increases cerebral blood flow. In dogs the average increase in cortical blood flow was $30 \mathrm{ml} . / 100 \mathrm{~g} / \mathrm{min}(47 \%)$ when the intracranial pressure was lowered acutely from 100 to $40 \mathrm{~mm}$ CSF. Permanent intracranial hypotension was established in seven demented patients using a ventriculoatrial shunt. The mean post shunt pressure was $50 \mathrm{~mm}$ CSF. In this group, the cerebral vascular resistance decreased $32 \%$, the cortical blood flow increased $37 \%$, and the relative weight of functional grey matter increased $44 \%$. The systemic blood pressure was $8 \%$ lower. The increase in cerebral blood flow is the result of an increase in the pressure differential between the precapillary arterioles and the veins. In addition, the vessels dilate in response to the decreased external pressure. This increase in cerebral blood flow may be the mechanism for improvement in patients with normal pressure hydrocephalus who are shunted.

This is the report of an experimental and clinical study of the effects of lowering intracranial pressure on cerebral blood flow. The study is an attempt to determine the mechanism of improvement in patients with normal pressure hydrocephalus.

\section{METHODS}

Cerebral blood flow was determined using the inert radioactive gas ${ }^{133} \mathrm{Xe}$. This isotope is a gamma emitter which permits counting through the intact skull. After its injection into the carotid artery, xenon diffuses in a known ratio between the blood and brain tissue. This is a purely physical process and depends only on diffusion and solubility. The gas is almost completely cleared in the lung as it is approximately $\mathbf{1 0}$ times more soluble in air than blood. On completion of the injection the carotid arterial blood contains virtually no xenon. The rate at which the xenon is washed out of the brain tissue varies with the quantity of blood perfusing the brain. The faster the flow of blood, the faster the radioactive material is removed from the brain. This is the basic principle for determining cerebral blood flow using the clearance technique (Harper, Glass, Steven, and Granat, 1964). The technique and calculations of Høedt-Rasmussen, Sveinodottir, and Lassen (1966) were used. The blood flow of the grey matter $\left(\mathrm{CBF}_{\mathrm{G}}\right)$, the blood flow of the white matter $\left(C B F_{w}\right)$, and the relative weight of the grey matter $\left(W_{G}\right)$ were calculated. All values were corrected

${ }^{1}$ Reprint requests to Dr. Salmon, 3200 Vine Street, Cincinnati, Ohio 45220, U.S.A. to a standard arterial $\mathrm{pCO}_{2}\left(\mathrm{apCO}_{2}\right)$ of $40 \mathrm{~mm} \mathrm{Hg}$. Using the systolic blood pressure and $\mathrm{CBF}_{\mathrm{G}}$, the cerebral vascular resistance $\left(\mathrm{CVR}_{\mathrm{G}}\right)$ of the cortical vessels was determined.

In previous studies of 54 dogs using this technique, little variation in CBF was found on sequential determination in an individual dog. Our values in normal animals (Salmon, 1969) were comparable with those from other laboratories (Harper, Glass, and Glover, 1961).

Seven animals were studied. After the dog was anaesthetized with pentobarbital and an endotracheal tube inserted, a small catheter was placed in the carotid artery and a no. 18 gauge needle in the cisterna magna. A scintillation detector, collimated to cover the estimated area of one cerebral hemisphere, was placed high on the cranial convexity. The intracranial pressure (ICP), the systolic (SBP) and mean (MBP) blood pressure, and the arterial $\mathrm{pCO}_{2}$ were monitored. However, in two dogs the $\mathrm{apCO}_{2}$ was not within the range of 35 to $50 \mathrm{~mm} \mathrm{Hg}$ and the study was discarded, since the correction factor is less reliable at the extremes of hypo- and hypercarbia. Each dog served as its own control. CBF studies were done at normal ICP and at $40 \mathrm{~mm}$ CSF pressure. ICP was varied by withdrawing cerebrospinal fluid or infusing saline via the cisternal cannula. The pressure was maintained at each new level for 30 minutes before the blood flow was determined. In preliminary studies, inconsistent results were obtained on duplicate studies without this equilibration period. This may relate to an intracranial pressure gradient. To determine the effect of time on the preparation, the ICP was returned to the original level after three hours and the CBF study repeated in two dogs. These data approximated to the baseline values. 
TABLE 2

Table 1 lists the effects of changes in intracranial pressure in a representative dog. As the intracranial pressure is lowered in a stepwise fashion there is a decrease in cerebrovascular resistance and an increase in blood flow through both the grey and white matter. The increase in $\mathrm{CBF}_{\mathrm{G}}$ is much more apparent. When the intracranial pressure is $40 \mathrm{~mm}$ of $\mathrm{CSF}$, the $\mathrm{CBF}_{\mathrm{G}}$ is increased to $175 \%$ of the basal value. There is no significant change in the systolic blood pressure (or mean pressure) in the course of the experiment. The magnitude of the change in $\mathrm{CBF}_{\mathrm{G}}$ is much greater when the intracranial pressure is lowered than when the pressure is elevated to over twice the basal value.

The ICP was lowered to $40 \mathrm{~mm}$ CSF in the dogs listed in Table 2. This is approximately the intracranial pressure in patients who have had a lowpressure Holter valve inserted. This level of pressure is associated with a $27 \%$ decrease in CVRG. This results in a $47 \%$ increase in $\mathrm{CBF}_{\mathrm{G}}$ and a $36 \%$ increase in $\mathrm{CBFw}_{\mathrm{w}}$. The systolic blood pressure increased in three dogs, decreased in one and was unchanged in one. The mean blood pressure (not listed) remained at $125 \mathrm{~mm} \mathrm{Hg}$ in no. 7, increased from 115 to 120 in no. 10 , increased from 130 to 150 in no. 11 , increased from 125 to 135 in no. 14 , and remained at 135 in no. 16.

A high degree of scepticism should be maintained in regard to compartmental analysis of cerebral blood flow in the dog. The internal carotid artery is a rather insignificant structure (dwarfed by the blood vessel to the tongue) and all xenon injections must of necessity be made into the common carotid artery. This results in a great deal of extracerebral contamination and we have had little success in extracting this third exponential. We offer this bit of data to suggest that cerebral blood flow can be increased by intracranial hypotension in the normal animal as well as in the demented human.

TABLE 1

ACUTE RESPONSE OF CBF TO CHANGE IN INTRACRANIAL PRESSURE IN THE DOG

\begin{tabular}{rcccc}
\hline$I C P$ & $C B F_{\mathrm{G}}$ & $C B F_{\mathrm{W}}$ & $C V R_{\mathrm{G}}$ & $S B P$ \\
\hline 100 & 66 & 8 & $2 \cdot 4$ & 160 \\
80 & 78 & 14 & $2 \cdot 1$ & 165 \\
40 & 116 & 15 & $1 \cdot 4$ & 160 \\
210 & 61 & 9 & $2 \cdot 7$ & 165 \\
\hline
\end{tabular}

ICP-Intracranial pressure in $\mathrm{mm}$ CSF. $\mathrm{CBF}_{\mathrm{G}}$-cerebral blood flow of grey matter in $\mathrm{ml} . / 100 \mathrm{~g} / \mathrm{min}$. $\mathrm{CBF}_{\mathrm{w}}$-blood flow of white matter. $\mathrm{CVR}_{\mathrm{G}}$-resistance of the cortical vessels. SBP-systolic blood pressure in $\mathrm{mm} \mathbf{H g}$.
CHANGES IN CBF WITH ACUTE INTRACRANIAL HYPOTENSION:

\begin{tabular}{|c|c|c|c|c|c|}
\hline Dog & $I C P$ & $C B F_{\mathrm{G}}$ & $C B F_{\mathrm{W}}$ & $C V R_{G}$ & $S B P$ \\
\hline 7 & $\begin{array}{r}100 \\
40\end{array}$ & $\begin{array}{l}82 \\
95\end{array}$ & $\begin{array}{l}10 \\
13\end{array}$ & $\begin{array}{l}2 \cdot 1 \\
1.9\end{array}$ & $\begin{array}{l}175 \\
180\end{array}$ \\
\hline 10 & $\begin{array}{r}100 \\
40\end{array}$ & $\begin{array}{r}66 \\
116\end{array}$ & $\begin{array}{r}8 \\
15\end{array}$ & $\begin{array}{l}2 \cdot 4 \\
1 \cdot 4\end{array}$ & $\begin{array}{l}160 \\
160\end{array}$ \\
\hline 11 & $\begin{array}{r}110 \\
40\end{array}$ & $\begin{array}{l}49 \\
70\end{array}$ & $\begin{array}{l}13 \\
18\end{array}$ & $\begin{array}{l}3 \cdot 7 \\
2 \cdot 8\end{array}$ & $\begin{array}{l}180 \\
195\end{array}$ \\
\hline 14 & $\begin{array}{r}170 \\
40\end{array}$ & $\begin{array}{r}85 \\
100\end{array}$ & $\begin{array}{l}11 \\
12\end{array}$ & $\begin{array}{l}2 \cdot 1 \\
1.9\end{array}$ & $\begin{array}{l}160 \\
185\end{array}$ \\
\hline 16 & $\begin{array}{r}120 \\
40\end{array}$ & $\begin{array}{r}59 \\
107\end{array}$ & $\begin{array}{l}15 \\
17\end{array}$ & $\begin{array}{l}3.0 \\
1.6\end{array}$ & $\begin{array}{l}175 \\
170\end{array}$ \\
\hline Mean change & -80 & +30 & +3.6 & -0.7 & +8 \\
\hline $\begin{array}{l}\text { Mean percent } \\
\text { change }\end{array}$ & $-65 \%$ & $+47 \%$ & $+36 \%$ & $-27 \%$ & $+5 \%$ \\
\hline
\end{tabular}

ICP lowered by withdrawing cisternal fluid. Approximately one hour between CBF determinations. All values are corrected to standard apCO $_{2}$ of $40 \mathrm{~mm} \mathrm{Hg}$. ICP-Intracranial pressure in mm CSF. CBF $\mathrm{F}-$ cerebral blood flow of grey matter in $\mathrm{ml} . / 100 \mathrm{~g} / \mathrm{min}$. CBFw-blood flow of white matter. $\mathrm{CVR}_{\mathrm{G}}$-resistance of the cortical vessels. $\mathrm{SBP}-$ systolic blood pressure in $\mathrm{mm} \mathrm{Hg}$. $\mathrm{W}_{\mathrm{G}}$-relative weight of grey matter in per cent.

CLINICAL STUDY

Cerebral blood flow was measured in patients who were scheduled to have a ventriculoatrial shunto Since this was a heterogeneous group, brief clinicas summaries are given below. The CBF technique wass similar to that described above. The internal carotid artery was cannulated. This catheter was used to inject the xenon, to withdraw samples for arterial $\mathrm{pCO}_{2}$ determinations, and to record the blood pressure using a transducer. A scintillation detector was placed over the forehead and collimated to cover the approximate area of one cerebral hemisphere. Intracranial pressure was determined by lumbar or lateral cervical puncture.

After the initial evaluation, intracranial hypotension was created by diverting the cerebrospinal fluid to the vascular system using a ventriculoatrial shunt (Fig. 1). This device, commonly used in the treatment of infantile hydrocephalus, contains a oneway valve which opens over a specified pressure range. Ordinarily a low pressure Holter valve, which reduces the intracranial pressure to subnormal levels, was used. The post-shunt pressure was approximately $50 \mathrm{~mm}$ CSF.

\section{CASE REPORTS}

F.R. was 54 years old when evaluated in January 1970 because of progressive difficulty with walking and a 


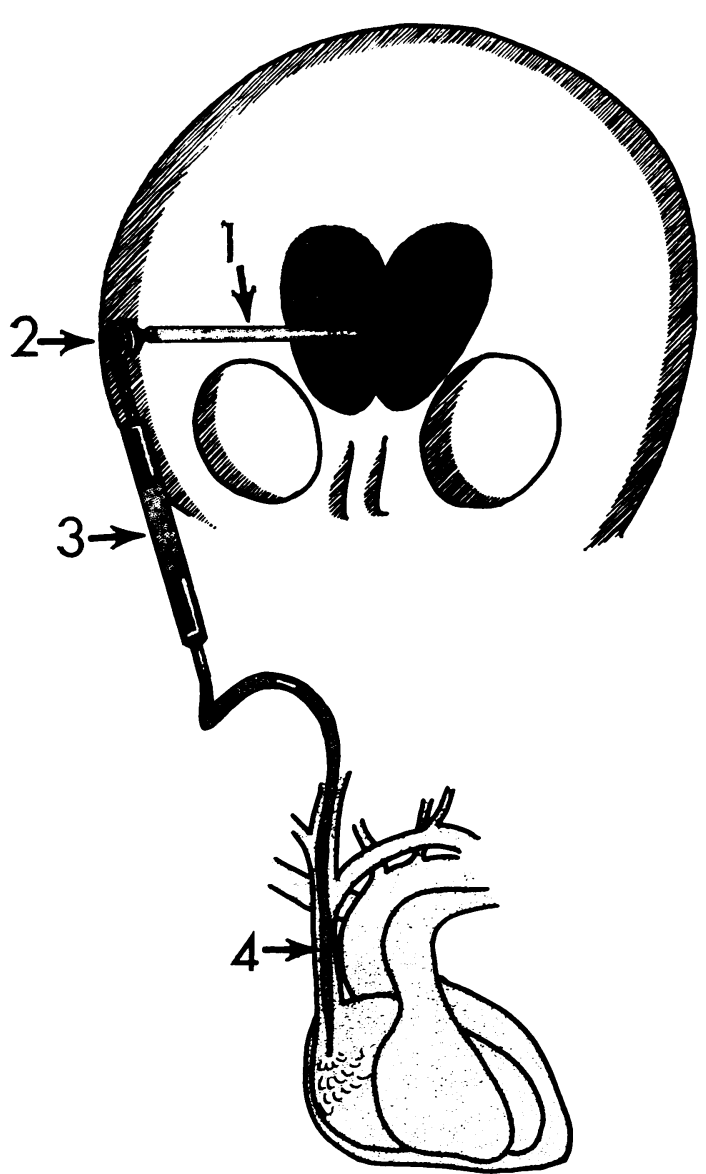

FIG. 1. The ventriculoatrial shunt drains CSF from the lateral ventricle of the brain to the right atrium via the jugular vein. The ventricular catheter (1) is inserted through a small burr-hole. The subcutaneous Salmon-Rickham reservoir (2) may be tapped to record intracranial pressure or to inject medication. The low pressure Holter valve (3) controls the rate and direction of flow of CSF and prevents regurgitation of blood into the shunt system. The atrial catheter (4) is introduced via the external jugular vein and positioned in the right atrium with ECG control.

burning sensation in his feet for two years. He had urinary urgency and occasional incontinence. His family was aware of some decrease in memory and judgment. He was oriented. Responses were superficial and concrete and he was functioning at the dull normal level. He was spastic in his lower extremities. His gait was wide-based with scissoring. There were no signs of peripheral neuropathy. Skull radiographs showed an enlarged sella turcica and a carotid angiogram suggested hydrocephalus. CBF studies were performed. A ventriculogram showed marked hydrocephalus with a frontal cerebral mantle (CM) of $18 \mathrm{~mm}$ and a supramesencephalic arachnoid cyst.
A ventriculoatrial shunt and fenestration of the cyst wall were performed.

CBF studies were repeated on 1 June 1970. The patient was cooperative and alert. He had less trouble expressing himself and was able to deal with more complex tasks. His gait was wide based but he walked with confidence. He was continent. He no longer required hospitalization.

H.S., 29 years old, received a severe head injury on 5 August 1969. When evaluated in April 1970, he appeared alert but responded only with 'Yes' and 'No' answers. There was a left hemiparesis. He required two assistants to walk and was incontinent of urine. Nonabsorptive hydrocephalus was demonstrated by RISA cisternography and pneumoencephalography (CM 23 $\mathrm{mm}$ ). A ventriculoperitoneal shunt was done on 9 April 1970.

Repeat CBF was performed two months later. A marked clinical improvement was apparent. He was alert, oriented, and cooperative with good recent memory. Psychological testing was impossible previously but his IQ was now 90. He walked with a cane and except for occasional urinary incontinence at night was continent.

R.C. This 42 year old male was evaluated because of lethargy, weakness, and seizures for one year. He tried to cooperate and responded but had difficulty in understanding all but the simplest requests. He could not copy simple designs. There was a mild left hemiparesis. Two assistants were required for walking and he was completely incontinent.

A pneumoencephalogram showed a $3 \times 4 \mathrm{~cm}$ right frontal porencephalic cyst and extensive cortical atrophy. The left frontal $C M$ was $50 \mathrm{~mm}$. The aetiology was uncertain. A cystoatrial shunt was established on 1 December 1969.

Repeat CBF was performed on 21 February 1970. The patient was alert, cooperative, and able to give short, factual answers to questions. On tasks requiring reasoning, verbal facility, or memory he did very poorly. He had better motor control and was able to walk alone in an abnormal manner. He was continent.

$R . W$. This 47 year old male had increasing dementia for two years. Memory, both recent and remote, was impaired. He was unable to walk alone and was frequently incontinent. His IQ was 65.

The air study showed minimal convexity air and a CM of $33 \mathrm{~mm}$. A ventriculoperitoneal shunt was inserted on 24 July 1969. The brain biopsy showed marked atrophy of cortex and white matter.

At the time of repeat CBF study, the patient was alert, oriented, and could walk alone. He was continent. His IQ had increased to 117 .

$W . W$. This 58 year old chronic alcoholic was seen in May 1969 because of disorientation and unsteady gait for two years. Diabetes mellitus, peripheral neuropathy, and Wernicke's encephalopathy had been diagnosed in the past. Pneumoencephalography failed to demonstrate air beyond the sylvian fissure. The cerebral mantle was $44 \mathrm{~mm}$.

A functioning ventriculoatrial shunt was placed on 30 July 1969. The brain biopsy was reported as normal cerebral cortex.

At the time of repeat CBF in October 1969, no apparent 
change from the preoperative status was seen. He was alert and cooperative but his recent memory remained impaired. His gait was unsteady.

$R . W . I I$, a 22 year old male, was evaluated in November 1969 because of diplopia, vomiting, and inability to walk. He had been struck by mine fragments in Vietnam on 25 March 1968. He was unconscious for 22 days. Posttraumatic atrophy of the left side of the brain had been demonstrated. The patient was alert, oriented, and able to carry out simple commands. He was dysphasic and had a right hemiparesis, the arm more involved than the leg. He would not attempt to walk alone but could with two assistants. A RISA cisternogram showed increased activity over the atrophic hemisphere. A ventriculoatrial shunt was placed on 3 December 1969

At the time of repeat CBF study on 6 February 1970, the patient showed little change. He was more cheerful and interested in the ward activities. The vomiting and diplopia had subsided. He could walk with one assistant and enthusiastically participated in physical therapy.

$W . H$. This 20 -year-old male was rendered decerebrate by shell fragments that entered the left frontoparietal area on 17 September 1968. Extensive debridement was complicated by brain abscess and meningitis. In February 1969 he was akinetic and mute. He would follow the examiner with his eyes and respond by nodding his head 'Yes' inappropriately. He did not show decerebrate posturing but could perform no useful movement. A ventriculogram demonstrated moderate non-absorptive hydrocephalus. The frontal cerebral mantle was $31 \mathrm{~mm}$.

At the time CBF studies were repeated on 5 June 1969, the patient was alert, smiling, and able to participate in therapy. He was able to read, spell, and complete simple number skills. Using his left hand he could feed himself, use an electric typewriter, and propel a wheel chair.

He was subsequently discharged to his home. His IQ was then 65 .

\section{RESULTS}

The cerebral blood flow values of seven patients are listed in Table 3. A fairly characteristic pattern

TABLE 3

EFFECT OF INTRACRANIAL HYPOTENSION ON CEREBRAL BLOOD FLOW

\begin{tabular}{|c|c|c|c|c|c|c|}
\hline & & $I C P$ & $C B F_{\mathrm{G}}$ & $W_{G}$ & $C V R_{\mathrm{G}}$ & $S B P$ \\
\hline F.R. & $\begin{array}{l}3 \text { Feb. } 70 \\
7 \text { Feb. } 70 \\
1 \text { June } 70 \\
\text { Change }\end{array}$ & $\begin{array}{c}130 \\
\text { Shunted } \\
60 \\
-54 \%\end{array}$ & $\begin{array}{c}49 \\
82 \\
+67 \%\end{array}$ & $\begin{array}{c}28 \\
36 \\
+29 \%\end{array}$ & $\begin{array}{r}1.8 \\
1.4 \\
-22 \%\end{array}$ & $\begin{array}{c}90 \\
114 \\
+27 \%\end{array}$ \\
\hline H.S. & $\begin{array}{l}6 \text { Apr. } 70 \\
9 \text { Apr. } 70 \\
17 \text { June } 70 \\
\text { Change }\end{array}$ & $\begin{array}{c}150 \\
\text { Shunted } \\
40 \\
-73 \%\end{array}$ & $\begin{array}{c}35 \\
\\
53 \\
+50 \%\end{array}$ & $\begin{array}{c}20 \\
24 \\
+20 \%\end{array}$ & $\begin{array}{r}2.6 \\
1.8 \\
-31 \%\end{array}$ & $\begin{array}{r}92 \\
94 \\
0\end{array}$ \\
\hline R.C. & $\begin{array}{l}4 \text { Nov. } 69 \\
1 \text { Dec. } 69 \\
21 \text { Feb. } 70 \\
\text { Change }\end{array}$ & $\begin{array}{c}140 \\
\text { Shunted } \\
68 \\
-51 \%\end{array}$ & $\begin{array}{c}36 \\
\\
54 \\
+50 \%\end{array}$ & $\begin{array}{c}32 \\
38 \\
+19 \%\end{array}$ & $\begin{array}{r}3.9 \\
1.6 \\
-59 \%\end{array}$ & $\begin{array}{c}140 \\
90 \\
-36 \%\end{array}$ \\
\hline R.W. & $\begin{array}{c}10 \text { July } 69 \\
23 \text { July } 69 \\
6 \text { Oct. } 69 \\
\text { Change }\end{array}$ & $\begin{array}{c}190 \\
\text { Shunted } \\
50 \\
-74 \%\end{array}$ & $\begin{array}{c}33 \\
43 \\
+30 \%\end{array}$ & $\begin{array}{r}29 \\
35 \\
+21 \%\end{array}$ & $\begin{array}{r}4 \cdot 2 \\
3 \cdot 3 \\
-21 \%\end{array}$ & $\begin{array}{r}140 \\
140 \\
0\end{array}$ \\
\hline w.w. & $\begin{array}{c}17 \text { June } 69 \\
30 \text { July } 69 \\
8 \text { Oct. } 69 \\
\text { Change }\end{array}$ & $\begin{array}{c}75 \\
\text { Shunted } \\
40 \\
-47 \%\end{array}$ & $\begin{array}{r}46 \\
59 \\
+28 \%\end{array}$ & $\begin{array}{c}21 \\
37 \\
+76 \%\end{array}$ & $\begin{array}{r}2.6 \\
1.8 \\
-31 \%\end{array}$ & $\begin{array}{c}120 \\
106 \\
-12 \%\end{array}$ \\
\hline R.W.II & $\begin{array}{r}14 \text { Nov. } 69 \\
8 \text { Dec. } 69 \\
6 \text { Feb. } 70 \\
\text { Change }\end{array}$ & $\begin{array}{c}140 \\
\text { Shunted } \\
65 \\
-54 \%\end{array}$ & $\begin{array}{c}37 \\
45 \\
+22 \%\end{array}$ & $\begin{array}{c}31 \\
39 \\
+26 \%\end{array}$ & $\begin{array}{r}4 \cdot 1 \\
2 \cdot 5 \\
-39 \%\end{array}$ & $\begin{array}{c}150 \\
115 \\
-23 \%\end{array}$ \\
\hline W.H. & $\begin{array}{c}27 \text { Feb. } 69 \\
13 \text { Mar. } 69 \\
5 \text { June } 69 \\
\text { Change }\end{array}$ & $\begin{array}{c}200+ \\
\text { Shunted } \\
40 \\
-80 \%\end{array}$ & $\begin{array}{c}40 \\
44 \\
+10 \%\end{array}$ & $\begin{array}{c}18 \\
40 \\
+120 \%\end{array}$ & $\begin{array}{r}3.3 \\
2.5 \\
-24 \%\end{array}$ & $\begin{array}{c}130 \\
110 \\
-15 \%\end{array}$ \\
\hline Mean change & & -95 & +16 & +10 & $-1 \cdot 1$ & -14 \\
\hline Mean per cent change & & $-62 \%$ & $+37 \%$ & $+44 \%$ & $-32 \%$ & $-8 \%$ \\
\hline
\end{tabular}

All values are corrected to a standard apCO $\mathrm{CO}_{2} 40 \mathrm{~mm} \mathrm{Hg}$. ICP-Intracranial pressure in mm CSF. CBF - cerebral blood flow of grey matter in $\mathrm{ml} . / 100 \mathrm{~g} / \mathrm{min}$. CBFw-blood flow of white matter. CVRG-resistance of the cortical vessels. SBP-systolic blood pressure in mm $\mathrm{Hg}$. $W_{G}$-relative weight of grey matter in per cent. 
evolves. After the intracranial pressure is lowered, $\mathrm{CVR}_{\mathrm{G}}$ decreases. $\mathrm{CBF}_{\mathrm{G}}$ and $\mathrm{W}_{\mathrm{G}}$ increase. $\mathrm{CBF}$, not listed in the Table, shows a variable response, sometimes increasing a few millilitres and at other times decreasing several millilitres. The greatest change was a decrease from 19 to $12 \mathrm{ml}$. per $100 \mathrm{~g}$ per min (patient W.H.) and the greatest increase was (patient R.W.) from 12 to $16 \mathrm{ml}$. per $100 \mathrm{~g}$ per min.

For the group as a whole, when the intracranial pressure was lowered $62 \%$, the cerebral vascular resistance decreased $32 \%$. This was associated with an increase in blood flow through the grey matter of $37 \%$ and an increase in functional grey matter of $44 \%$.

The preoperative intracranial pressure in all but one of the patients was below $200 \mathrm{~mm}$ CSF. Three of the patients had modest systolic hypertension. The blood pressure fell an average of $8 \%$ for the group after intracranial hypotension was created.

\section{DISCUSSION}

The $\mathrm{CBF}_{\mathrm{G}}$ in this group of patients is quite low, as would be expected since all were demented (Obrist, Chivian, Cronqvist, and Ingvar, 1970). Even after intracranial hypotension, only one patient's $\mathrm{CBF}_{\mathbf{G}}$ approaches the normal value of $80 \mathrm{ml}$. per $100 \mathrm{~g}$ grey matter per minute.

The relative weight of grey matter $\left(\mathrm{W}_{\mathrm{G}}\right)$ is approximately $50 \%$ in a normal animal as determined by anatomical measurements, radioautography, or the xenon technique. We do not believe that the $W_{G}$ values we find in symptomatic patients are the same as the anatomical grey matter which would be found at necropsy. We feel that $W_{G}$ as measured with xenon represents that portion of the brain that is functioning as grey matter and receiving a commensurate blood flow. Is dementia the result of an inadequate blood supply to the grey matter or is the grey matter receiving all of the blood that is required at its decreased level of function? $\mathrm{W}_{\mathrm{G}}$ seems to be a useful and pertinent concept. It seems to increase with increasing neurological function and also to be decreased in the presence of dementia. We have not seen any patient who showed clinical improvement who did not also have an increase in $\mathrm{W}_{\mathrm{G}}$. Patient W.H. showed a very dramatic improvement in his clinical state and this was reflected in the $120 \%$ increase in $\mathbf{W}_{\mathbf{G}}$. An increase in $\mathbf{W}_{\mathbf{G}}$ does not necessarily mean that the patient will improve, however. Patient W.W. had a $76 \%$ increase in $\mathrm{W}_{\mathrm{G}}$ but did not improve with intracranial hypotension. Structural damage in the area of the hypothalamus, midbrain, and peripheral nerves in this alcoholic patient may have prevented any improvement. An increase in function of cortical neurones is of no use to the patient if the distal, effector neurones have been destroyed.

The postoperative blood pressure was lowered in four patients. This would be expected because the cerebrovascular resistance within the cerebral vessels decreased and less pressure was required for flow. This seems to indicate that autoregulation was intact in these patients. In an attempt to demonstrate that autoregulation was intact in our animal model, the systolic blood pressure was elevated to $300 \mathrm{~mm} \mathrm{Hg}$ using various pharmacological agents. There was no appreciable change in cerebral blood flow.

Greitz, Grepe, Kalmér, and Lopez (1969) studied patients with angiography and xenon cerebral blood flow before and after a shunt. From the description, their patients were less severely involved than some in our series and had a somewhat larger $W_{G}$. All of their patients had a markedly abnormal $\mathrm{CBF}_{\mathrm{G}}$. The correlation between postoperative improvement and an increased $\mathrm{W}_{\mathrm{G}}$ was quite dramatic. The correlation between postoperative improvement and change in $\mathrm{CBF}_{\mathrm{G}}$ was poor.

The $\mathrm{W}_{\mathrm{G}}$ was as low as $29 \%$ in the series of Greitz and colleagues and $18 \%$ in the patient who demonstrated akinetic mutism in our series. We have recorded a $W_{G}$ of $10 \%$ in a patient with an acute subdural haematoma and cerebral contusion who was comatose. Zingesser, Schechter, Dexter, Katzman, and Scheinberg (1968) reported a $W_{G}$ of $4.9 \%$ in a patient with subarachnoid haemorrhage. Unfortunately, no description of this patient was given.

MECHANISM OF INCREASE IN BLOOD FLOW The blood flow through a vessel varies with the pressure differential between the feeding artery and the draining vein, the diameter of the involved vessel, and the viscosity of the blood. Intracranial hypotension influences the first two. The most significant force which causes blood to flow through the brain is the pressure differential between the carotid arteries and the draining veins (Fig. 2). Venous pressure very closely approximates to the intracranial pressure. The pressure in the precapillary arterioles (estimated as 30 to $35 \mathrm{~mm} \mathrm{Hg}$ ) (Brock, Hadjidimos, Deruaz, $1971)$ is directly related to tissue perfusion. When the intracranial pressure (and venous pressure) is lowered from the pre-shunt level of $10 \mathrm{~mm} \mathrm{Hg}$ to $3 \mathrm{~mm} \mathrm{Hg}$, a significant change in the perfusion pressure differential results. The pre-shunt pressure differential between tissue perfusion and venous pressure would be 30 minus 10 or $20 \mathrm{~mm} \mathrm{Hg}$. After the venous pressure is lowered to $3 \mathrm{~mm} \mathrm{Hg}$, the pressure differential increases to $27 \mathrm{~mm} \mathrm{Hg}$, a $35 \%$ increase. This increase in pressure differential causes an increase in cerebral blood flow.

The external pressure on the side walls of a 

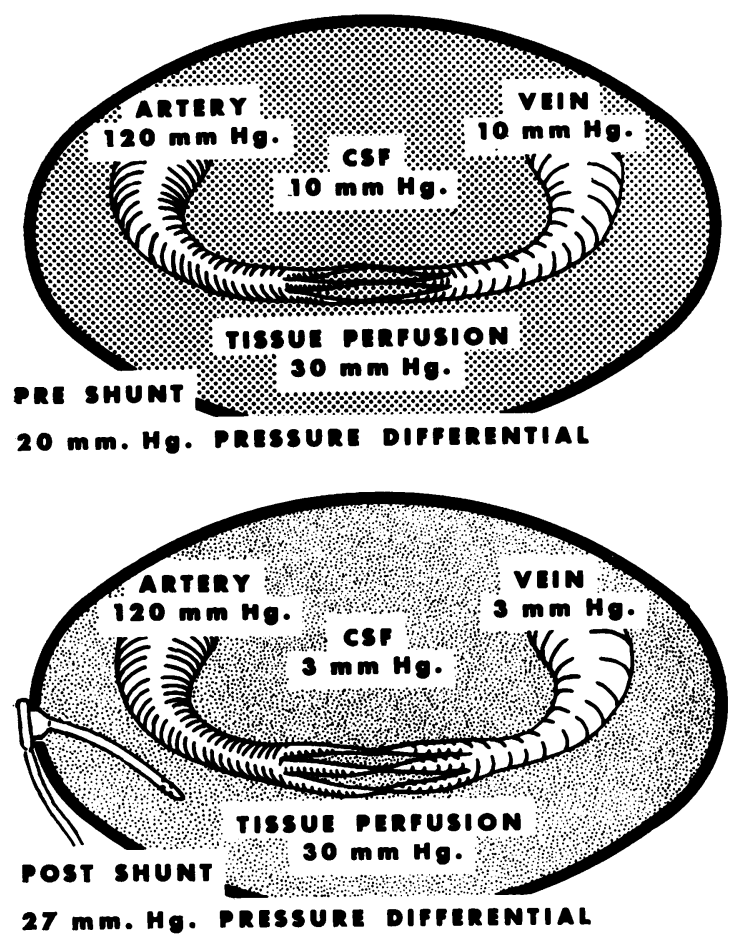

FIG. 2. Cerebral blood flow improves with intracranial hypotension because of the increase in the tissue perfusionvenous pressure differential. The vessels also dilate because the external pressure on their walls is decreased.

collapsible vessel influences the diameter of the vessel (Lassen, 1959). When the intracranial pressure is lowered, there is less pressure on the external surface of the artery. The artery dilates and permits increased flow. This is logical but it seems to contradict the findings of Langfitt, Weinstein, and Kassell (1965), who found that cerebral vascular dilatation was a constant response to intracranial hypertension. Hekmatpanah (1970) agrees that vascular dilatation occurs with increased intracranial pressure but maintains that this vascular engorgement occurs mainly in the veins rather than the arteries. 'In fact, $x$-ray study with the injection of barium sulfate disclosed that the cortical arteries were narrowed, as when cerebral angiography is performed in patients with increased intracranial pressure.' We are unaware of any study in which intracranial vessels were observed under conditions of decreased intracranial pressure.

In order to determine if CBF would be increased by intracranial hypotension in a patient with cerebrovascular disease, Brock et al. (1970) lowered the CSF pressure from 12 to $8 \mathrm{~mm} \mathrm{Hg}$ by withdrawing cerebrospinal fluid. While the mean arterial pressure and $\mathrm{apCO}_{2}$ remained substantially unchanged, the average CBF increased $9 \%$, with regional increases amounting to $60 \%$.

A system that would maintain intracranial pressure at a low level, day and night, week after week, might be useful in treating patients with cerebral ischaemia without infarction. The ventriculoatrial shunt is such a system.

Dr. John J. Imarisio (Chief, Radioisotope Section) provided valuable guidance and assistance. Richard $\mathrm{L}$. Clark, R.B.P., furnished the illustrations. Blood gas analysis was done by Alfred McCoy and Joseph Penn. George Shwaery assisted in the animal work.

\section{REFERENCES}

Brock, M., Hadjidimos, A. A., Deruaz, J. P. (1971). The effects of hyperventilation on regional cerebral blood flow. On the role of changes in intracranial pressure for shifts inCBF distribution. In Proceedings 1970 Princeton Con ference on Cerebral Vascular Disease. (In press.)

Greitz, T. V. B., Grepe, A. O. L., Kalmér, M. S. F., ancक্ Lopez, J. (1969). Pre- and postoperative evaluation of cerebral blood flow in low-pressure hydrocephalus. $J$ Neurosurg., 31, 644-651.

Harper, A. M., Glass, H. I., and Glover, M. M. (1961) Measurement of blood flow in the cerebral cortex of dogs by the clearance of Krypton-85. Scot. med. J., 6, 12-17.

Harper, A. M., Glass, H. I., Steven, J. L., and Granat, A. H. (1964). The measurement of local blood flow in the cerebral cortex from the clearance of Xenon ${ }^{133}$. J. Neurol. Neurosurg. Psychiat., 27, 255-258.

Hekmatpanah, J. (1970). Cerebral circulation and perfusion in experimental increased intracranial pressure. J. Neurosurg, 32, 21-29.

Høedt-Rasmussen, K., Sveinsdottir, E., and Lassen, N. A. (1966). Regional cerebral blood flow in man determined by the intra-arterial injection of radioactive inert gas. Circulat. Res., 18, 237-247.

Langfitt, T. W., Weinstein, J. D., and Kassell, N. F. (1965). Cerebral vasomotor paralysis produced by intracranial hypertension. Neurology (Minneap.), 15, 622-641.

Lassen, N. A. (1959). Cerebral blood flow and oxygen consumption in man. Physiol. Rev., 39, 183-238.

Obrist, W. D., Chivian, E., Cronqvist, S., and Ingvar, D. H. (1970). Regional cerebral blood flow in senile and presenile dementia. Neurology (Minneap.), 20, 315-322.

Salmon, J. H. (1969). Cerebral blood flow in intracranial hemorrhage-evaluation of arterial spasm with Xenon ${ }^{133}$. In Current Topics in Surgical Research, edited by G. D. Zuidema, and D. B. Skinner, Vol. 1, pp. 205-218. Academic Press: New York.

Zingesser, L. H., Schechter, M. M., Dexter, J., Katzman, R., and Scheinberg, L. C. (1968). Relationship between cerebral angiographic circulation time and regional cerebral blood flow. Invest. Radiol., 3, 86-91. 